\title{
Fight Coronavirus Disease (COVID-19): More Active People for a Healthier World: Physical Activity Recommendations
}

\author{
Nevzat DEMIRCí ${ }^{1}$ \\ ${ }^{1}$ Faculty of Sports Science, Trainer Education Department, Mersin University, 33110 Mersin, Turkey \\ *Corresponding author: ijdshs@gmail.com
}

Keywords

Physical Activity, COVID-19, Exercise, Public Health, Active People

During the end of 2019 and the beginning of 2020, multiple human cases of novel coronavirus infection were reported in relation to the Huanan Seafood Wholesale Market (South China Seafood City Food Market) in Wuhan, China. At 9 O'clock, 7 January 2020, the virus was identified as a novel coronavirus and officially named by the WHO as 2019-nCoV, the new coronavirus in 2019. COVID-19 is thought to spread mainly through close contact from person-to-person in respiratory droplets from someone who is infected. People who are infected often have symptoms of illness. Some people without symptoms may be able to spread virus (WHO, 2020). In addition, based on the worldwide information fromthe Covid-19 pandemic, some characteristics of the population at higher risk for Covid-19 have been identified, such as being older people, those with hypertension, Cancer, Type 2 diabetes, Osteoporosis, sarcopenia, Depression, Anxiety, Cognitive function or cardiovascular disease (CVD) risk factors and patients with respiratory diseases or conditions (Lavie et al., 2019; Demirci et al., 2018; McKinney et al., 2016).

Ensuring that all people have access to safe and conducive environments and opportunities to be physically active in their daily lives, improving the health of individuals and society and contributing to the social, cultural and economic development of all nations. The objective is to achieve a relative reduction of $15 \%$ in the global prevalence of physical inactivity in adults and adolescents by 2030 (WHO, 2018). These lifestyles and behaviors in many cases include a certain level of physical activity (PA) and exercise to maintain an adequate health status, to counteract the negative consequences of certain diseases (Ozemek et al., 2019), such as diabetes, hypertension, CVD, respiratory diseases, or even simply to guarantee an active aging by reducing the risk of frailty, sarcopenia and dementia, as associated diseases in older people (Fletcher et al., 2018). Therefore, to not totally interrupt or change the lifestyle of people during quarantine and tomaintain an active lifestyle at home is very important for the health of the overall population but, especially, for thosewith additional risk factors and older people.

The reason to promote physical activity for improving physical fitness components is that these (cardiorespiratory fitness, muscular strength, coordinationagility) are directly related with the physiological functions of the main organ systems (respiratory, circulatory, muscular, nervous and skeletal systems) and indirectly implicated in the appropriate functioning of other systems (endocrine, digestive, immune systems) (Imboden et al., 2019; Liu et al., 2019). Regular physical activity is one of the most important activities you can do for your health. For all of us, young and old, regular physical activity is important for staying healthy! Compared to just sitting around most of the time, moderate-intensity physical activity is associated with better immune function. 
Regular physical activity can help reduce your feelings of stress and anxiety (which many of us may be feeling in the wake of the COVID-19 pandemic). More active people for a healthier world: The Physical activity guidelines for recommends 150-300 minutes per week of moderate-intensity aerobic physical activity and 2 sessions per week of muscle strength training. Fit in $2,5,10$ or 20 minutes, however and wherever you can. Every active minute counts!

Physical Activity It is a well-known preventive factor for the prevention and treatment of leading noncommunicable diseases (NCDs). It also helps prevent the risk factors for other important communicable diseases such as (Covid19) (Rhodes et al., 2017). Regular physical activity participation was associated with prevention of more than 25 chronic medical conditions (Lavie et al., 2019; Warburton, Taunton, Bredin and Isserow, 2016). For example, systematic reviews of the literature (Warburton et al., 2010) have shown that there was an average risk reduction of 20-30\% for multiple chronic medical conditions in people who was regularly. In physically active subjects, (such as cardiovascular disease, stroke, hypertension, colon and breast cancer, and Type 2 diabetes), the relative risk reductions observed for many chronic medical conditions have a significant impact on the population (Table 1 . WHO, 2020-a; WHO, 2018-b; Lippi et al., 2020; Lippi and Sanchis-Gomar, 2020).

\section{Table 1. To Fight Coronavirus Disease (COVID-19): Health-Related Benefits of Physical Activity}

\begin{tabular}{|c|c|}
\hline Age Groups & Children \\
\hline 0- 4 Years & Improved bone health and weight status \\
\hline 5-17 Years & $\begin{array}{l}\text { Improved cognitive function (ages 6-13). Improved cardiorespiratory and } \\
\text { fitness. Improved bone health Improved cardiovascular risk factor status. } \\
\text { Improved weight status and adiposity Less depression symptoms }\end{array}$ \\
\hline 18-64 Years & Adults of all ages \\
\hline Death due to all causes & Low risk \\
\hline Cardiometabolic Situations & $\begin{array}{l}\text { Low cardiovascular incidence and mortality (including heart disease and stroke). } \\
\text { Low incidence of hypertension Lower incidence of type } 2 \text { diabetes }\end{array}$ \\
\hline Cancer & $\begin{array}{l}\text { Lower incidence of bladder, breast, colon, endometrium, esophagus, kidney, } \\
\text { stomach and of lung cancers }\end{array}$ \\
\hline Brain Health & $\begin{array}{l}\text { Brain health Decreased risk of dementia Improved cognitive function. Improved } \\
\text { cognitive function following aerobic activity. Improved quality of life. Improved } \\
\text { sleep. Decreased anxiety and feelings of depression in healthy individuals and } \\
\text { people with current clinical syndromes. Incidence of reduced depression }\end{array}$ \\
\hline Weight status & $\begin{array}{l}\text { Reduced risk of excessive weight gain. Weight loss and the prevention of weight } \\
\text { regain following initial weight loss when a sufficient dose of moderate-to- } \\
\text { vigorous physical activity is attained an additive effect on weight loss when } \\
\text { combined with moderate dietary restriction }\end{array}$ \\
\hline Above 65 aged & Older Adults \\
\hline Falls & Reduced incidence of falls. Reduced incidence of fall-related injuries \\
\hline Physical function & Improved physical function in older adults with and without frailty \\
\hline & Patients \\
\hline & Women who are Pregnant or Postpartum \\
\hline During pregnancy & $\begin{array}{l}\text { Reduced risk of excessive weight gain. Reduced risk of gestational diabetes. No } \\
\text { risk to fetus from moderate intensity physical activity }\end{array}$ \\
\hline During postpartum & Reduced risk of postpartum depression \\
\hline & Individuals with Pre-Existing Medical Conditions \\
\hline Upper respiratory infection & Reduced systemic imflammation \\
\hline Breast cancer & Reduced risk of all-cause and breast cancer mortality \\
\hline Prostate cancer & Reduced risk of prostate cancer mortality \\
\hline Osteoarthritis & Decreased pain. Improved function and quality of life \\
\hline Hypertension & $\begin{array}{l}\text { Reduced risk of progression of cardiovascular disease. Reduced risk of } \\
\text { increased blood pressure over time }\end{array}$ \\
\hline Type 2 diabetes & $\begin{array}{l}\text { Reduced risk of cardiovascular mortality. Reduced progression of disease } \\
\text { indicators: hemoglobin A1c, blood pressure, blood lipids, and body mass index }\end{array}$ \\
\hline Multiple sclerosis & Improved walking. Improved physical fitness \\
\hline Dementia & Improved cognition \\
\hline
\end{tabular}


There is likely to be very limited opportunity to practise physical activity outdoors during this period, with most people forced to stay at home or adopt isolation protocols to prevent transmission of the virus. It is thus recommended that people should stay active by exercising at home. For this purpose, multiple exercise modes can be applied, including aerobic exercise using stationary bikes or rowing ergometers, bodyweight strength training, dance-based exercise and active gaming (Hammami et al., 2020). The aim should be to undertake at least $30 \mathrm{~min}$ of moderate physical activity every day and/ or at least $20 \mathrm{~min}$ of vigorous physical activity every other day. Ideally, a combination of both intensities of physical activities is preferable in addition to practicing strengthening-type activities on a regular basis. 18 Children, the elderly, and those who have previously experienced symptoms of illness or are susceptible to chronic cardiovascular or pulmonary disease should seek advice from health care providers about when it is safe to exercise. (Table 2. WHO, 2018-b; WHO, 2018-c; Liu et al., 2017; Colberg et al., 2010).

Table 2. More Active People for a Healthier World: Physical Activity Recommendations

\begin{tabular}{|c|c|}
\hline Age Groups & Aerobic Activity \\
\hline $0-4$ Years & $\begin{array}{l}\text { For } 1-4 \text { year olds, } \geq 180 \text { min of physical activity at any intensity on all } \\
7 \text { days of the week }\end{array}$ \\
\hline 5- 17 Years & $\begin{array}{l}\geq 60 \text { min of moderate to vigorous intensity physical activity on all } 7 \\
\text { days of the week }\end{array}$ \\
\hline 18- 64 Years & $\begin{array}{l}\geq 150 \mathrm{~min} / \text { week of moderate aerobic activity, or } \geq 75 \mathrm{~min} / \text { week of } \\
\text { vigorous activity or an equivalent combination of moderate and } \\
\text { vigorous activity accumulated in bouts of } \geq 10 \mathrm{~min}\end{array}$ \\
\hline Above 65 aged & $\begin{array}{l}\geq 150 \mathrm{~min} / \text { week of moderate aerobic activity, or } \geq 75 \mathrm{~min} / \text { week of } \\
\text { vigorous activity or an equivalent combination of moderate and } \\
\text { vigorous activity accumulated in bouts of } \geq 10 \mathrm{~min}\end{array}$ \\
\hline & Patients \\
\hline Upper respiratory infection & $\begin{array}{l}\sqrt{ } / \times, 10 \text {-minute jog test: If the general condition and signs are changed: } \\
\text { allow low to moderate physical activity }(<80 \% \text { of VO deteriorated: } \\
\text { prohibit physical activity until full recovery; If not } 2 \text { max })\end{array}$ \\
\hline Cancer-related fatigue & $3 \mathrm{x} /$ week for $30 \mathrm{~min}$ per session of moderate intensity \\
\hline Health-related quality of life & $2-3 x /$ week for $30-60 \mathrm{~min}$ per session of moderate to vigorous \\
\hline Physical Function & $3 \mathrm{x} /$ week for $30-60 \mathrm{~min}$ per session of moderate to vigorous \\
\hline Lymphedema & $\begin{array}{l}\text { 2-3x/week of progressive, supervised, program for major muscle } \\
\text { groups does not exacerbate lymphedema }\end{array}$ \\
\hline Hypertension & $\begin{array}{l}>2-3 \text { sessions per week/ }>20-30 \text { min per session of continuous or } \\
\text { accumulated exercise of any duration. Moderate }(40 \%-59 \% \text { VO2R } \\
\text { or; Vigorous } 60 \%-80 \% \text { VO2R) }\end{array}$ \\
\hline Diabetes & $\begin{array}{l}\text { Aerobic exercise should be at least at moderate intensity, } \\
\text { corresponding approximately to } 40-60 \% \text { of } \mathrm{Vo} 2 \mathrm{max} \text { (maximal aerobic } \\
\text { capacity) or vigorous exercise }(>60 \% \text { of } \mathrm{Vo} 2 \mathrm{max}) \text {. }\end{array}$ \\
\hline During pregnancy & $\begin{array}{l}\text { Women should accumulate } 150 \text { minutes of moderate } \geq 150 \mathrm{~min} / \text { week of } \\
\text { moderate aerobic activity but should occur over a minimum of } 3 \text { days } \\
\text { per week. }\end{array}$ \\
\hline Weight status (obesity) & $\begin{array}{l}3 \mathrm{x} / \text { week for } 20-40 \text { min per session of moderate to vigorous aerobic } \\
\text { exercise, plus } 2-3 \mathrm{x} / \text { week of resistance training } 2 \text { sets of } 8-12 \text { reps for } \\
\text { major muscle group at moderate to vigorous intensity }\end{array}$ \\
\hline
\end{tabular}

Given the concerns about the increasing spread of COVID-19, it is imperative that infection control and safety precautions be followed. Home stay is a fundamental safety step that can limit infections from spreading widely. But prolonged home stays can increase behaviors that lead to inactivity and contribute to anxiety and depression, which in turn can lead to a sedentary lifestyle known to result in a range of chronic health conditions. Maintaining regular physical activity and routinely exercising in a safe home environment is an important strategy for healthy living during the coronavirus crisis. 
As a result; physical activity is important across all ages, and should be integrated into multiple daily settings. Whether working or not, older adults, in particular, can benefit from regular physical activity to maintain physical, social and mental health (including prevention or delay of dementia), prevent falls and realize healthy ageing. Strengthening the provision of, and access to appropriate opportunities and programmes can enable all older adults to maintain an active lifestyle according to capacity. In the protection and treatment of diseases, it is recommended to increase the level of physical activity and to make life style changes and to ensure continuity.

\section{REFERENCES}

Colberg S.R., Sigal R.J., Fernhall B, Regensteiner J.G., Blissmer B.J., Rubin R.R., et al. (2010). Exercise and Type 2 Diabetes. Diabetes Care.Dec; 33(12): e147-e167.

Demirci N, Yıldırım İ, Toptaş Demirci P And Ersöz Y. (2018). Why Should We Do Physical Activity? More Active People For A Healthier World. Int J Disabil Sports Health Sci;1(2);1-14

Fletcher GF, Landolfo C, Niebauer J, Ozemek C, Arena R, Lavie CJ. (2018). Promoting physical activity and exercise: JACC health promotion series. J Am Coll Cardiol 2018;72(14):1622-1639.

Hammami A, Harrabi B, Mohr M. \& Krustrup P. (2020). Physical activity and coronavirus disease 2019 (COVID-19): specific recommendations for home-based physical training, Managing Sport and Leisure, DOI: 10.1080/23750472.2020.1757494

Imboden MT, Harber MP, Whaley MH, et al. (2019). The association between the change in directly measured cardiorespiratory fitness across time and mortality risk. Prog Cardiovasc Dis;62(2):157-162.

Lavie CJ, Ozemek C, Carbone S, Katzmarzyk PT, Blair SN. (2019). Sedentary behavior, exercise, and cardiovascular health. Circ Res;124(5):799-815.

Lippi G, Henry MB, Sanchis-Gomar F. (2020). Physical inactivity and cardiovascular disease at the time of coronavirus disease 2019 (COVID19). Eur J Prev Cardiol; in pres.

Lippi G, Sanchis-Gomar F. (2020). An estimation of the worldwide epidemiologic burden of physical inactivity-related ischemic heart disease. Cardiovasc Drugs Ther;34:133-7.

Liu X, Zhang D, Liu Y, et al. (2017). Dose-Response Association Between Physical Activity and Incident Hypertension: A Systematic Review and
Meta-Analysis of Cohort Studies. Hypertension; 69(5):813-820.

Li G, Fan Y, Lai Y, Han T, Li Z, Zhou P, et al. (2020). Coronavirus infections and immune responses. J Med Virol. 2020;92:424-432. DOI: 10.1002/jmv.25685

Liu Y, Lee DC, Li Y, et al. (2019). Associations of resistance exercise with cardiovascular disease morbidity and mortality. Med Sci Sports Exerc;51(3):499-508.

Ozemek C, Lavie CJ, Rognmo. (2019). Global physical activity levels: need for intervention. Prog Cardiovasc Dis;62(2):102-107.

McKinney J, Daniel J, Lithwick MHA, Barbara N. Morrison BHK, Nazzari H, et al. (2016). The health benefits of physical activity and cardiorespiratory fitness. bc medical journal vol. 58 no. 3, april

Rhodes RE, IJanssen I, Bredin SSD, Warburton ERD \& Bauman A (2017). Physical activity: Health impact, prevalence, correlates and interventions. Psychology \& Health, 32:8, 942-975.

Warburton, D. E. R., Taunton, J., Bredin, S. S. D., \& Isserow, S. (2016). The risk-benefit paradox of exercise. BC Medical Association Journal, 58, 210-218.

Warburton, D. E., Charlesworth, S., Ivey, A., Nettlefold, L., \& Bredin, S. S. (2010). A systematic review of the evidence for Canada's physical activity guidelines for adults. International Journal of Behavioral Nutrition and Physical Activity, 7, 39. doi:10.1186/1479-58687-39.

World Health Organization (2020-a). Laboratory testing of human suspected cases of novel coronavirus $(\mathrm{nCoV})$ infection [published online ahead of print January 21, 2020]. https://apps.who.int/iris/bitstream/handle/10665/ 330374/WHO-2019-nCoV-laboratory 2020.1eng.pdf

World Health Organization (2018-b). Physical Activity Guidelines Advisory Committee Scientific Report, February 2018, Part D: Integrating the Evidence.Visithttps://health.gov/paguidelines/sec ondedition/ report.aspx to access the entire report.

World Health Organization (2018-c). Physical activity guidelines for Americans. 2nd ed. Washington, DC: U.S. Department of Health and Human Services; 2018.

How to cite this article: Demirci, N. (2020). Fight Coronavirus Disease (COVID-19): More Active People for a Healthier World: Physical Activity Recommendations. Int J Disabil Sports Health Sci;3(1):14. DOI:10.33438/ijdshs. 731146 